\title{
Online Peer Assessment Untuk Mengembangkan Keterampilan Presentasi Oral Diskusi Kelompok Kecil pada Pembelajaran IPS
}

\author{
Nuansa Bayu Segara1, Hermansyah², \\ 1 nuansasegara@unesa.ac.id,2Hermansyah.mpd@yahoo.com \\ ${ }^{1}$ Universitas Negeri Surabaya ${ }^{2}$ Universitas Swadaya Gunung Djati
}

Submitted

September 27, 2019
Revised

December 19, 2019

http://dx.doi.org/10.17509/jpis.v28i2.20191
Accepted

December 20, 2019

\section{ABSTRACT}

One goal of developing soft skills in the social studies class on higher education student is communication skill. This article explains how to effect peer assessment to developing communication skill, especially oral presentation in the small group discussion. The subject in this research is 51 students Faculty Education of Universitas Swadaya Gunung Djati Cirebon who contract social studies class. The research design is an experimental study. The design consisted of two groups an experimental and control. Instruments used to measure an oral presentation is a valid and reliable rubric, can be accessed online. Based on the result of research, there is a significant effect on online peer assessment to oral presentation skill in the small group discussion. Students have a role to be a respectable assessor. They assess the oral presentation colleagues objectively and authentic. Online peer assessment is useful for the assessment process. Besides that, students obtain feedback for improving oral presentation performance.

Keywords: peer assessment, communication skils, oral presentation, online assesment, rubric

\section{ABSTRAK}

Tujuan pengembangan soft skills dalam perkuliahan pendidikan IPS di perguruan tinggi salah satunya adalah keterampilan komunikasi. Artikel ini mengungkap bagaimana pengaruh online peer assessment dalam mengembangkan keterampilan komunikasi, khususnya presentasi oral dalam diskusi kelompok kecil. Subjek penelitian ini adalah 51 mahasiswa Fakultas Pendidikan Universitas Swadaya Gunung Djati Cirebon yang mengontrak mata kuliah pendidikan IPS. Desain penelitian ini merupakan eksperimen, dengan kelompok eksperimen dan kontrol. Instrumen yang digunakan untuk mengukur presentasi oral adalah rubrik penilaian yang valid dan reliabel dan diakses secara online. Hasil penelitian menunjukan bahwa terdapat pengaruh yang signifikan penggunaan online peer assessment terhadap keterampilan presentasi oral mahasiswa dalam diskusi kelompok kecil. Mahasiswa dapat berperan dengan baik sebagai asessor bagi rekanrekannya. Mereka melakukan penilaian presentasi oral dengan objektif dan benar-benar autentik. Online peer assessment sangat efektif untuk proses penilaian. Selain itu, mahasiswa mendapatkan umpan balik untuk memperbaiki performa presentasi.

Kata kunci: peer assessment, keterampilan komunikasi, presentasi oral, online assesment, rubrik penilaian

\section{PENDAHULUAN}

Universitas memiliki peran penting untuk mengembangkan keterampilan mahasiswa yang dibutuhkan di era informasi dalam revolusi industri 4.0 ini. Universitas harus memiliki cara dalam 
mengembangkan soft skills yang dibutuhkan oleh mahasiswa. Mereka membutuhkan soft skills yang menunjang pekerjaan dan aktivitasnya di masa yang akan datang. Beberapa keterampilan yang dibutuhkan dalam menyiapkan mahasiswa untuk siap menghadapi era ini adalah berpikir kritis, kreativitas, kolaborasi, literasi, komunikasi dan jaringan kerja (1-3). Komunikasi merupakan salah satu keterampilan yang sangat penting bagi mahasiswa. Satu keterampilan komunikasi yang dibutuhkan dunia bisnis, profesional, dan lingkungan ilmiah adalah presentasi, mahasiswa harus memiliki banyak kesempatan belatih dalam mengungkapkan pemikiran, ide dan gagasan $(4,5)$, hal itu dapat dilakukan pada proses perkuliahan agar keterampilan presentasinya berkembang.

Mahasiswa Pendidikan Ekonomi, Universitas Swadaya Gunung Djati (UGJ) Cirebon, wajib mengontrak mata kuliah pendidikan IPS. Satu soft skills yang diharapkan berkembang adalah keterampilan komunikasi. Presentasi merupakan keterampilan komunikasi yang sangat dibutuhkan oleh mahasiswa calon guru. Faktanya, mahasiswa masih memiliki keterampilan presentasi oral yang belum cukup baik, meskipun sudah menggunakan peer assesment dalam proses pembelajaran (6). Peer assessment sebenarnya sangat membantu mahasiswa yang berperan sebagai asesor dan presenter untuk mendapatkan umpan balik, untuk meningkatkan keterampilan yang diharapkan $(7,8)$. Namun, proses peer assement yang dilakukan untuk menilai presentasi oral mahasiswa belum mendapatkan hasil yang optimal.
Terdapat tiga dimensi yang dapat diukur dalam penilaian presentasi oral yaitu dimensi konten, dimensi pengiriman pesan dan dimensi kolaborasi $(5,9,10)$. Berdasarkan studi sebelumnya, dimensi konten merupakan keterampilan terendah dalam presentasi oral mahasiswa, disusul oleh dimensi pengiriman pesan dan kolaborasi (11).

Terdapat beberapa hal yang menyebabkan presentasi oral mahasiswa melalui peer assessment belum optimal. Pertama, standar kompetensi pada setiap indikator penilaian presentasi oral belum dipelajari dan dipahami betul oleh mahasiswa. Kedua, peer assessment membuat mahasiswa tegang, karena ada perasaan segan ketika mendapatkan judgement dari rekannya sendiri. Ketiga, mahasiswa belum benarbenar memanfaatkan umpan balik dalam penerapan peer assessment. Keempat, proses presentasi secara massal membuat mahasiswa tidak dapat menunjukan performa terbaiknya. Masalah yang dihadapi mahasiswa tersebut yang membuat peer assessment presentasi oral belum berjalan secara optimal.

Sudah cukup banyak ditemukan penelitian yang berupaya untuk meningkatkan presentasi oral dengan melakukan peer assessment (9,12-17). Penelitian yang mempraktikan peer assessment secara online dalam melakukan penilaian juga sudah dilakukan oleh beberapa ahli (18). Seperti penelitian yang dilakukan van Ginkel et al., (2017) tentang peer assessment dalam presentasi oral, hasilnya menunjukan bahwa terdapat hubungan yang subtansial kuat antara perkembangan kognisi, sikap dan 
perilaku terhadap presentasi mahasiswa. Fokus penelitian ini adalah untuk mengungkap umpan balik dalam meningkatkan keterampilan presentasi oral. Beberapa penulis mengungkap terdapat perbedaan antara penilaian sejawat dengan yang dilakukan dosen, ada kecenderungan mahasiswa memberikan penilaian yang lebih tinggi (19). Namun, berbeda dengan penelitian tersebut, mahasiswa UGJ melakukan penilaian yang sangat objektif, sehingga menunjukan hasil yang belum cukup baik dalam praktik presentasi oral (6).

Berdasarkan permasalahan yang ditemui dalam praktik pembelajaran, serta melihat adanya gap kajian dalam online peer assessment dalam presentasi oral. Untuk itu, diputuskan melakukan kajian praktik online peer assessment dalam presentasi oral pada diskusi kelompok. Mahasiswa yang melakukan presentasi oral dalam kelompok kecil diharapkan agar dapat memiliki performa yang lebih baik. Online peer assessment juga dipraktikan untuk mempermudah proses penilaian dan mahasiswa ketika berperan menjadi asesor, mereka dapat dengan mudah mendapatkan umpan balik dari standar kriteria atau indikator presentasi oral. Penilaian online juga akan mempermudah proses pengolahan data penilaian, dan juga memiliki prinsip keterbukaan proses penilaian, sehingga penilaian lebih akuntabel. Fokus artikel ini adalah untuk 1) mendeskripsikan tingkat capaian presentasi oral mahasiswa yang dinilai secara online dengan peer assessment; 2) menganalisis pengaruh praktik online peer assessment dalam meningkatkan keterampilan presentasi oral pada diskusi kelompok kecil. dan 3) mengungkap respon mahasiswa pasca penggunaan online peer assessment dalam diskusi kelompok kecil.

\section{KAJIAN LITERATUR Presentasi Oral}

Satu keterampilan komunikasi lisan yang dibutuhkan era global saat ini adalah presentasi. Presentasi dibutuhkan oleh mahasiswa selama proses perkuliahan (20). Presentasi berbeda dengan mengajar dan juga dengan kemampuan berbicara lainnya. Presentasi merupakan salah satu kemampuan berbicara, biasanya presentasi dilakukan dalam pertemuan bisnis, tehnikal, profesional dan lingkungan ilmiah (5).

Pada penelitian ini keterampilan komunikasi yang dimaksud adalah presentasi ilmiah yang merupakan salah satu tugas mahasiswa setelah menyelesaikan laporan investigasi yang dibuat. Mahasiswa akan mempresentasikan hasil investigasi itu dalam sebuah forum ilmiah yaitu seminar studi sosial. terdapat tiga dimensi untuk mengukur performa presentasi oral mahasiswa, yaitu Content, Delivery dan Collaboration. Penilaian pada presentasi ini menggunakan sepuluh indikator yang dihimpun dari berbagai sumber seperti: 1) Penguasaan konten; 2 ) efektivitas dan fokus; 3) Kreativitas; 4) Kontak mata dan gestur; 5) komunikatif, 6) Volume; 7) Antusiasisme; 8) Bahasa formal; 9) Menjawab pertanyaan; 10) Kolaborasi kelompok $\quad(5,9,11)$. Berdasarkan indikator tersebut selanjutnya akan dibuat kriteria-kriteria yang mencerminkan level dari masing-masing indikator. Pembagian dalam rubrik dibagi menjadi empat level. Masingmasing level memiliki skor sehingga nanti akan menghasilkan sebuah nilai 
yang terukur dari observasi kemampuan presentasi oral tersebut.

Selain itu pendekatan lain yang digunakan dalam penilaian performa prsentasi oral adalah dengan peer assessment. Mahasiswa tidak saja dinilai oleh dosen pengampu, akan tetapi mereka dinilai oleh rekan sekelasnya, dan juga mereka akan menilai rekan sekelasnya. Hal ini dimaksudkan untuk melibatkan mahasiswa dalam proses penilaian, juga sebagai motivasi agar menunjukan performas yang baik di mata rekan sekelasnya.

\section{Peer assessment}

Peer assessment bukanlah pendekatan yang baru dalam dunia pendidikan. Peer assessment adalah sebuah pengatudan bagi pembelajar untuk mempertimbangkan atau menentukan secara spesifik, nilai atau kualitas performa sesama rekannya (7). Peer assessment dapat digunakan dalam penilaian sumatif ataupun formatif. Dengan melibatkan rekan sekelas yang dilakukan secara seksama dan hati-hati tentu saja peer assessment dapat digunakan sebagai komponen dalam penilaian sumatif (16).

Jadi dalam perkuliahan ini, peer assessment bukan merupakan teknik penilaian satu-satunya untuk menentukan hasil perkuliahan, namun masuk dalam komponen penilaian sumatif perkuliahan. Terdapat beberapa penelitian yang mengungkap keuntungan ketika selama perkuliahan menggunakan peer assessment untuk meningkatkan kemampuan presentasi oral (13,21). Penggunaan peer assessment perlu dilakukan untuk menolong mahasiswa melatih kemampuan presentasi oral, karena dengan hal itu mereka dapat merefleksikan kelemahan dan kelebihan, juga akan berusaha untuk bertanggung jawab dalam proses perkuliahan (22).

Terdapat langkah-langkah yang dilakukan untuk memulai peer assessment dalam penelitian ini. Pertama, menjelaskan kepada mahasiswa pentingnya peer assessment. Mereka harus sadar bagaimana pentingnya peran-peran yang diabangun selama proses perkuliahan. Kedua, penilaian dipraktikan secara perlahan, dan format penilaian dibuat sangat mudah (secara online) dan tidak bersifat mengancam, biarkan mahasiwa merasa dipercaya oleh dosen. Ketiga, mahasiswa diberikan kesempatan untuk menangkap umpan balik dari proses peer assessment. Langkah-langkah tersebut membuat peserta didik akan memiliki tanggung jawab dalam peran masing-masing, sebagai assessor atau pun sebagai presenter yang dinilai (23).

\section{METODE PENELITIAN}

Desain penelitian ini adalah eksperimen semu yang terdiri dari dua kelompok, yaitu kelompok eksperimen dan kontrol. Eksperimen digunakan dalam penelitian ini karena untuk mengetahui pengaruh peer assessment online terhadap presentasi oral pada diskusi kelompok kecil. Lokasi penelitian ini di sebuah Universitas Swadaya Gunung Djati di Cirebon dengan partisipan sebanyak 51 mahasiswa Pendidikan Ekonomi yang mengontrak mata kuliah Pendidikan IPS. Terdapat beberapa instrumen yang digunakan dalam penelitian ini, seperti: 1) perangkat perkuliahan; 2) panduan praktik investigasi kelompok dan presentasi oral; 3) instrumen penilaian 
presentasi oral yang dilengkapi dengan rubrik kriteria, dan 4) respon mahasiswa terhadap proses penilaian presentasi oral.

Penilaian presentasi oral ini didasari dari tiga dimensi dan sepuluh indikator dengan sedikit perubahan istilah (11). Dimensi pertama adalah "Konten" yang terdiri dari 3 indikator yaitu 1) materi; 2) fokus dan 3) kreatifitas. Dimensi kedua adalah "pengiriman pesan" terdiri dari 5 indikator, yaitu: 1) Gestur; 2) Komunikasi; 3) Antusiasme; 4) Volume, dan 5) Bahasa. Dimensi ketiga adalah "kolaborasi" yang terdiri dari 2 indikator, yaitu: 1) Kolaborasi kelompok dan 2) Menjawab Pertanyaan. Penilaian online dibantu dengan google form. Dosen dapat melakukan kontrol ketika ada mahasiswa yang ditugaskan melakukan penilaian, tapi tidak melakukannya.

Instrumen penilaian presentasi oral yang digunakan dalam penelitian ini sudah melakukan pengujian validitas dan reliabilitas. Teknik confirmatory factor analysis dibantu oleh smartPLS 3.0 digunakan dalam melakukan uji validitas dan reliabilitas ini. Hasil pengujian tersebut menyatakan bahwa seluruh komponen penilaian presentasi oral adalah valid. Berdasarkan nilai Average Variance Extracted (AVE) pada tiap dimensi yaitu sebagai berikut, dimensi konten dengan nilai 0,687 ; dimensi pengiriman pesan dengan nilai 0,567; dan dimensi kolaborasi dengan nilai 0,747 (lihat Segara, Yana, \& Febianti, 2018). Melihat hal tersebut maka, seluruh nilai AVE pada dimensi tersebut berada di atas 0,5 dan seluruh nilai factor loading dari sepuluh indikator penilaian presentasi oral juga berada di atas 0,5 yang artinya instrumen penilaian presentasi oral memiliki validitas yang tinggi (24). Sedangkan, untuk reliablitas instrumen presentasi oral dilihat dari nilai composite reliability dengan nilai masing-masing tiap dimensi adalah sebagai berikut, untuk dimensi konten dengan nilai rho $=0,868$; dimensi pengiriman pesan dengan nilai rho = 0,855; dan dimensi kolaborasi dengan nilai rho $=0,867$. Berdasarkan nilai tersebut maka dapat disimpulkan instrumen presentasi oral yang digunakan memiliki reliabilitas yang sangat baik (25).

Pengambilan data dilakukan pada dua kelompok, yaitu eksperimen dan kontrol. Kelompok eksperimen adalah kelompok yang melakukan online peer assessment untuk presentasi oral dalam diskusi kelompok kecil, sedangkan kelompok kontrol online peer assessment untuk presentasi oral dalam diskusi kelompok kecil selama proses presentasi kelas secara konvensional.

Hasil penilaian presentasi oral yang telah dikumpulkan kemudian diolah dan dianalisis ketercapaianya dengan analisis persentasi. Hasilnya akan menentukan tingkat (level) ketercapaian presentasi oral mahasiswa. Selanjutnya, untuk mengetahui pengaruh dari peer assessment presentasi oral ini dilakukan uji perbedaan non-parametrik MannWhitney. Pengujian tersebut dilakukan karena setelah melakukan uji normalitas, terdapat salah satu kelompok yang tidak berdistribusi normal. Hasil pengujian ini akan mendapatkan kesimpulan apakah online peer assessment berpengaruh terhadap 
presentasi oral dalam diskusi kelompok kecil.

\section{HASIL DAN PEMBAHASAN}

Pada bagian ini peneliti akan fokus membahas proses pembelajaran dan hasil analisis data yang pada akhirnya mengerucut pada tiga hal, yaitu 1) proses penilaian; 2) capaian presentasi oral mahasiswa; 3) uji pengaruh; dan repspon mahasiswa terhadap online peer assessment ini.

\section{Proses penilaian}

Presentasi oral mahasiswa dilakukan setelah mereka melaksanakan praktik di lapangan dan menyelesaikan laporan praktik tersebut melalui proses bimbingan dosen. Terdapat beberapa fase yang digunakan dalam proses investigasi kelompok: 1) choosing topic/area; 2) formulating and design instrument; 3) Gathering data using the designed instrument; 4) and analysis of the data (Abordo \& Gaikwad, 2005). Setelah proses bimbingan selesai, mahasiswa bersepakat untuk melaksanakan presentasi pada seminar hasil investigasi. Proses penilaian presentasi oral pada kelas eksperimen menggunakan pendekatan Assessment as Learning ( $\mathrm{AaL})$. Pendekatan ini menekankan pada penggunaan asesmen sebagai proses mengembangkan dan mendukung metakognisi mahasiswa, dalam pengertian mahasiswa diberi kesempatan dan dibimbing untuk melakukan pemantauan dan menggunakan hasil pemantuan untuk memperbaiki belajarnya (26).

Presentasi oral pada kelas eksperimen dilakukan dengan metode diskusi kelompok kecil. Mereka melakukan prosees penilaian secara online yang dilakukan oleh teman sejawat. Setiap mahasiswa diberi kesempatan untuk menyampaikan presentasi hasil praktiknya selama 15 menit, dengan pembagian waktu sepuluh menit untuk presentasi, dan lima menit untuk tanya jawab. Mahasiswa yang berperan menjadi presenter dinilai oleh sebanyak 4-5 rekannya yang berperan sebagai asessor. Dosen ikut berpartisipasi dalam melakukan penilaian untuk menyeimbangkan penilaian teman sejawat. Pada kelas kontrol penilaian yang digunakan sama secara online dan dinilai oleh teman sejawat mahasiswa. Perbedaanya adalah metode presentasi pada di kelas kontrol dilakukan secara konvensional. Perwakilan setiap kelompok mendapatkan kesempatan untuk melakukan penilaian kepada presenter. Selain itu, sama seperti yang dilakukan pada kelas eksperimen, dosen juga ikut memberi penilaian untuk menyeimbangkan penilaian teman sejawat.

Penskoran dilakukan untuk mempermudah proses analisis dan justifikasi kriteria presentasi oral. Capaian kriteria presentasi oral ini dibuat menjadi 4 tingkat atau level, yaitu: poor dengan skor 1-69; fair dengan skor 70-79; good dengan skor 80-89 dan excellent dengan skor 90-100. Seluruh mahasiswa kelas eksperimen sudah mendapatkan indikator dan standar deskripsi untuk mendapatkan nilai terbaik dalam buku pedoman praktik investigasi. Hal itu diharapkan menjadi dasar bagi mahasiswa untuk melakukan latihan sebelum presentasi oral dilakukan. Mahasiswa juga akan mendapatkan umpan balik proses 
selama penilaian presentasi oral dilakukan. Umpan balik tersebut akan membantu mahasiswa mengetahui penampilan terbaik yang akan membuat mereka mendapatkan nilai terbaik. Proses penilaian selama presentasi oral juga membuat mahasiswa benar-benar fokus untuk menyimak rekannya yang berperan sebagai presenter, karena mereka memiliki tanggung jawab yang besar untuk menilai rekan-rekannya tersebut.

\section{Tingkat Presentasi Oral Mahasiswa}

Pasca melakukan penilaian teman sejawat data terhimpun secara online pada google document. Peneliti melakukan pengolahan data untuk mengklasifikasikan level presentasi oral mahasiswa. Penilaian mahasiswa dan dosen kemudian disatukan menjadi skor akhir. Seperti yang sudah disampaikan sebelumnya bahwa keterampilan presentasi ini dibagi menjadi empat level, yaitu: poor, fair, good dan excellent. Persentasenya dapat dilihat pada grafik berikut ini.

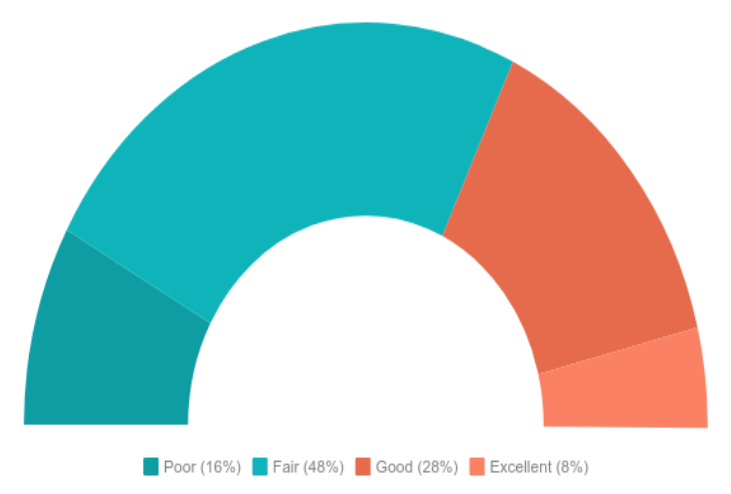

Sumber: Hasil penelitian 2019 Gambar 1. Tingkat Presentasi Oral Mahasiswa Kelompok Eksperimen

Gambar 1 menunjukan bahwa kurang dari setengah mahasiswa di kelas eksperimen memiliki keterampilan presentasi oral yang berada pada fair level. Sedangkan, kurang dari setengah lainnya mahasiswa memiliki keterampilan presentasi oral pada level good. Hanya sebagian kecil mahasiswa yang memiliki keterampilan excellent dalam presentasi oral, dan sebagian kecil lainnya masuk dalam poor level.

Penilaian ini melibatkan mahasiswa secara aktif untuk melakukan proses penilaian. Meskipun begitu dapat dilihat penilaian dilakukan secara objektif oleh mahasiswa. Mahasiswa juga selama melakukan proses penilaian mendapatkan feedback, sehingga mereka berusaha lebih baik dari pada rekannya yang dinilai. Meskipun begitu, masih sangat sulit mahasiswa mencapai level excellent, hal ini dikarenakan masih terdapat kekurangan yang dimiliki oleh mahasiswa dalam presentasi oral. Peneliti merasa ini merupakan hal yang wajar, karena mahasiswa ini merupakan mahasiswa tingkat satu yang masih belum banyak pengalaman untuk presentasi.

Proses yang sama dilakukan pada kelas kontrol, hanya saja penilaian hanya diwakili beberapa orang, sehingga tidak seluruh peserta mendapatkan feedback dari penampilan presenter. Oleh sebab itu, terlihat ada perbedaan jumlah mahasiswa pada setiap level keterampilan presentasi oral. Berikut ini merupakan tingkat presentasi oral mahasiswa di kelas kontrol. 


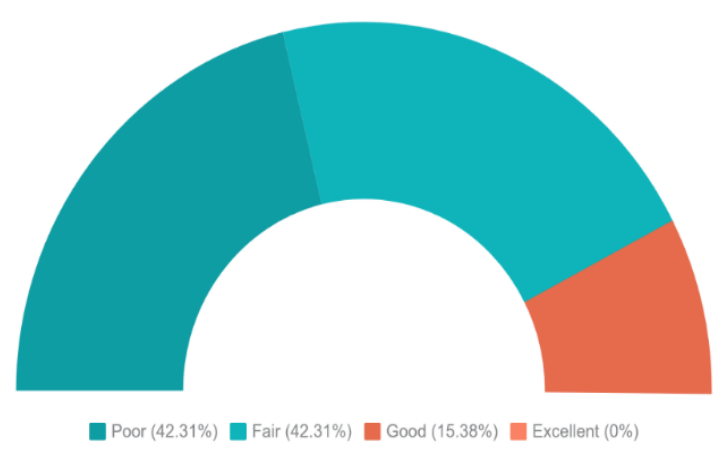

Sumber: Hasil penelitian 2019 Gambar 2. Tingkat Presentasi Oral Mahasiswa Kelompok Kontrol

Mahasiswa kelas kontrol terdiri dari 26 orang. Gambar 2 menunjukan bahwa kurang dari setengah mahasiswa memiliki keterampilan presentasi oral dalam level poor dan fair. Sebagian kecil lainnya memiliki keterampilan presentasi oral pada level Good. Sedangkan, untuk level excellent tidak ada satu orang mahasiswa yang mencapai level tersebut. Artinya terdapat 42,31\% mahasiswa belum mencapai skor 70 dan 42,31\% mahasiswa juga sudah mencapai skor 70. Mahasiswa yang memiliki keterampilan presentasi oral diantara skor 80-89 hanya sebesar $15,38 \%$.

Perbedaan tingkat capaian mahasiswa antara kelas eksperimen dan kelas kontrol perlu dianalisis lebih jauh. Hal yang perlu diungkap adalah capaian pada tiap indikator atau kompetensi yang masuk ke dalam penilaian presentasi oral. Perlu juga diketahui pada kompetensi mana mahasiswa secara general mencapai performa terbaiknya. Peneliti melakukan pengolahan data secara parsial per indikator. Perhitunganya dilakukan dengan cara, skor mahasiswa pada tiap indikator dijumlahkan lalu dibagi dengan maksimal skor, dan dikalikan seratus persen. Hasilnya adalah persentase capaian presentasi oral mahasiswa berdasarkan peer asessment pada tiap indikator. Tabel 1 di bawah ini akan mengungkap persentase capaian pada kelompok eksperimen dan kontrol.

Tabel 1. Persentase Capaian Presentasi Oral

\begin{tabular}{|c|c|c|c|}
\hline \multicolumn{4}{|c|}{ Mahasiswa } \\
\hline \multirow[t]{2}{*}{ No } & \multirow[t]{2}{*}{ Indikator } & \multicolumn{2}{|c|}{$\begin{array}{c}\text { Capaian Presentasi } \\
\text { Oral (\%) }\end{array}$} \\
\hline & & Eksperimen & Kontrol \\
\hline 1 & Materi & 78,16 & 74,16 \\
\hline 2 & Fokus & 68,90 & 77,50 \\
\hline 3 & Kreativitas & 67,93 & 77,15 \\
\hline 4 & Gestur & 75,95 & 69,00 \\
\hline 5 & Komunikasi & 79,88 & 74,79 \\
\hline 6 & Antusiasme & 79,53 & 69,13 \\
\hline 7 & Volume & 78,95 & 78,51 \\
\hline 8 & Bahasa & 77,90 & 73,78 \\
\hline 9 & $\begin{array}{l}\text { Menjawab } \\
\text { Pertanyaan }\end{array}$ & 77,45 & 70,06 \\
\hline 10 & Kolaborasi & 79,10 & 71,59 \\
\hline
\end{tabular}

Sumber: Hasil penelitian 2019

Presentasi oral mahasiswa dianalisis berdasarkan sepuluh indikator yang digunakan sebagai konstruk penilaian. Seluruh capaian indikator berada pada level fair. Capaian tertinggi ada pada indikator komunikasi, kriteria terbaik pada indikator ini adalah "berbicara dengan jelas, tanpa ada salah kata selama presentasi". Indikator dengan capaian tinggi lainnnya adalah antusiasme dengan kriteria terbaik "menunjukan ekspersi wajah dan bahasa tubuh yang penuh semangat, dan antusias tinggi selama presentasi. Capaian terendah adalah pada indikator gestur dengan kriteria terbaik "berdiri tegak, terlihat santai dan percaya diri, memandang semua audiens selama presentasi". Selain itu, seluruh indikator relatif memiliki capaian merata.

Sebenarnya hasil ini masih jauh dari harapan. Harapannya sebenarnya 
adalah mahasiswa dapat mencapai level good pada tiap indikator penilaian. Namun, mahasiswa menunjukan dengan hasil ini, bahwa mereka juga berusaha objektif dalam menilai. Mereka melakukan penilain sesuai dengan performa rekan sejawatnya selama presentasi. Hasil pada tiap indikator ini dapat dijadikan sebagai acuan pada proses perkuliahan lainnya, bahwa kekurangan-kekurangan yang dilakukan pada presentasi oral dapat diperbaiki.

\section{Uji Perbedaan}

Analisis selanjutnya adalah untuk membuktikan bahwa penggunaan assessmen alternatif memiliki pengaruh terhadap presentasi oral. Sebelum melakukan uji perbedaan maka ada uji prasyarat yang harus dilalui yaitu uji normalitas dan homogenitas data. Berikut tabel 2 yang menunjukan hasil uji normalitas dan homogenitas data.

Tabel 2. Hasil Uji Normalitas dan Homogenitas Data

\section{Kelompok}

Uji Prasyarat

\begin{tabular}{ccc}
\cline { 2 - 2 } & Normalitas & Homogenitas \\
\cline { 1 - 2 } $\mathbf{X}$ & 0,036 & 0,749 \\
\hline $\mathbf{0}$ & 0,055 & \\
\hline
\end{tabular}

Sumber: Hasil penelitian 2019

Uji normalitas data dilakukan dengan melakukan perhitungan Shapiro-Wilk. Tabel 2 menunjukan nilai $P$ values dari uji normalitas sebesar 0,036 pada kelompok eksperimen dan 0,055 pada kelompok kontrol. Hasil ini menunjukan bahwa pada kelas eksperimen data yang dihasilkan tidak normal, karena lebih kecil dari 0,05. Sedangkan untuk uji homogenitas menggunakan statistik levene. Hasilnya menunjukan bahwa data bersifat homogen, yang artinya berasal dari varian yang sama. Karena salah satu data tidak memenuhi uji prasyarat statistik parametrik, maka uji perbedaan dilakukan dengan statistik nonparametrik yaitu Uji Mann-Whitney U. Hasil perhitungan uji beda dapat dilihat pada tabel 3 berikut ini.

Tabel 3. Hasil Uji Perbedaan Mann-Whitney U

\begin{tabular}{ccccc}
\hline \multicolumn{2}{c}{ Rerata } & & P & Keputusan \\
\cline { 1 - 2 } $\mathbf{x}$ & $\mathbf{0}$ & & Value & \\
\cline { 5 - 6 } & 71,75 & 2,841 & 0,007 & $\begin{array}{c}\text { Berbeda } \\
\text { Signifikan }\end{array}$ \\
\hline
\end{tabular}

Sumber: Hasil penelitian 2019

Tabel 3 menunjukan bahwa terdapat perbedaan rata-rata kemampuan presentasi oral mahasiswa antara kelas eksperimen dengan kelas kontrol. Kelas eksperimen yang menggunakan proses assessmen alternatif dalam proses penilaian presentasi oral dalam diskusi kecil memiliki rata-rata sebesar 78,16. Sedangkan, untuk kelas kontrol yang melakukan penilaian assessment alternatif dalam proses penilaian dan seminar konvensional memiliki rata-rata sebsar 71,75.

Pembuktian bahwa terdapat perbedaan dilakukan dengan melihat nilai $P$ sebesar 0,007. Nilai tersebut lebih rendah dari nilai signifikansi $\alpha=0,05$. Hal ini berarti terdapat perbedaan keterampilan presentasi oral signifikan antara kelas eksperimen dengan kelas kontrol. Dapat disimpulkan bahwa penggunaan online peer assessment berpengaruh positif terhadap peningkatan keterampilan presentasi 
oral mahasiswa dalam diskusi kelompok kecil.

\section{Respon Mahasiswa}

Pasca proses penilaian mahasiswa diminta untuk memberi komentar dan saran selama melaksanakan proses penilaian presentasi oral. Respon mahasiswa dalam menanggapi proses presentasi online ini cukup positif. Terdapat beberapa mahasiswa memberi respon yang fokus pada presentasi oral dengan metode diskusi kelompok kecil. Berikut ini beberapa tanggapan dari mahasiswa yang terkait proses presentasi.

"Pada saat presentasi, jujur dari diri sendiri masih ada sedikit grogi karena belum terbiasa, tetapi dengan adanya presentasi seperti itu (diskusi kelompok kecil), saya dapat lebih belajar dan berlatih agar lebih merasa tenang dan tidap gugup selama presentasi." (Yovita)

Pada sebelum melakukan penilaian presentasi oral, mahasiswa telah diberikan rubrik kriteria penilaian, sehingga mahasiswa sebelum melakukan performa dapat berlatih dan mempelajari kriteria-kriteria di setiap penilaian. Selain berdampak pada presenter, peer assessment dalam diskusi kelompok kecil juga berdampak pada keseriusan pendengar dalam mendengarkan presentasi rekannya. Hal itu terjadi karena mereka juga berperan sebagai assessor penilaian presentasi. Sepertinya respon yang disampaikan oleh mahasiswa di bawah ini.

"Dalam melaksanakan presentasi ini rekan-rekan dapat mendengarkan dengan baik dan membuat yang presentasi pun menjadi rileks dan tidak canggung." (Siti)
Ketika presentasi berlangsung memang salah satu yang mempengaruhi penampilan mahasiswa adalah audiens. Mereka sangat terpengaruh audiens ketika tidak mendengarkan, seringkali mahasiswa kehilangan konsentrasinya. Terdapat pula mahasiswa yang merasa melakukan presentasi lebih baik dengan proses diskusi kelompok kecil. Seperti yang dialami oleh seorang mahasiswa berikut ini.

"Saat presentasi tidak ada kendala, karena metode diskusi kali ini berbeda dari biasanya (presentasi kelas). Sehingga saya merasa lebih bagus pada saat melaksanakan presentasi."(Yenny)

Selain respon positif terhadap metode presentasi oral pada diskusi kelompok kecil, banyak pula mahasiswa yang menanggapi proses penilaiannya, baik terkait dengan peer assessment dan juga online assessment. Berikut ini beberapa respon dari mahasiswa terkait hal tersebut.

"Penilaian menggunakan teknologi
secara online sudah bagus sekali,
sehingga data yang masuk dapat
langsung diolah oleh sistem dan
hanya mwmbutuhkan waktu yang
sedikit". (Fahmi) Tanggapan tersebut merupakan respon dari mahasiswa yang merasa bahwa penggunaan google form dalam penilaian ini sangat efektif dan merasa bahwa hal tersebut adalah baik bagi proses peer assessment. Selain itu, dengan proses seperti ini mahasiswa merasa perlu untuk bersikap objektif dalam proses penilaian. Seperti yang direspon oleh seorang mahasiswa berikut ini. 
"Pada melakukan penilaian kepada anggota kelompok lain cukup membingungkan pada awalnya, tetapi sedapat mungkin saya bersikap netral dalam menilai."(Ruliyani)

Dari respon tersebut nampak objektifitas mahasiswa sebagai penilai, meskipun di awal proses penilaian mengalami kebingungan, namun setelah proses berjalan, mahasiswa dapat bertanggung jawab dalam menilai rekannya.

Respon yang telah disampaikan mahasiswa tersebut, memperkuat bahwa apa yang dilakukan ini mendapatkan umpan balik yang positif, sehingga teknik penilaian alternatif ini tidak hanya dapat bermanfaat untuk mengembangkan keterampilan presentasi oral saja, namun ada soft skills lain yang mengiringinya, seperti tanggung jawab, kejujuran dan integritas akademik.

\section{SIMPULAN}

Berdasarkan analisis data dan pembahasan dapat diambil beberapa kesimpulan dalam penelitian ini. Capaian secara umum dari penggunaan online peer assessment dalam presentasi oral mahasiswa masuk dalam level fair yang artinya cukup. Hasil ini merupakan hasil yang terbaik dan menandakan penilaian yang dilakukan oleh sesama rekan mahasiswa dilakukan secara objektif dan autentik. Selanjutnya, dapat disimpulkna bahwa online peer assessment berpengaruh signifikan terhadap presentasi oral mahasiswa dalam diskusi kelompok kecil. Hal ini dibuktikan dengan hasil uji perbedaan Mann-Whitney $U$ dengan nilai signifikansi $p=0,07>0,5$. Terakhir adalah respon mahasiswa yang cukup positif terhadap pelaksanaan metode diskusi kelompok kecil dan proses penilaian presentasi oral secara peer dan online. Respon ini pun membuktikan bahwa proses penilaian alternatif ini dapat membantu mahasiswa untuk mengembangkan keterampilan presentasi oralnya.

\section{REKOMENDASI}

Berdasarkan hasil penelitian yang telah diungkapkan sebelumnya. Dapat diajukan beberapa rekomendasi bagi peneliti selanjutnya, atau praktisi pendidikan. Pertama, subjek penelitian ini hanya dilakukan di perguruan tinggi, sehingga masih ada kesempatan bagi peneliti lain untuk meneliti di tingkatan sekolah menengah dan dalam bidang studi lainnya yang membutuhkan keterampilan presentasi oral. Kedua, sebelum melaksanakan peer assessment dalam presentasi oral, harus dijelaskan secara detil komponen atau kriteria penilaian kepada siswa agar mereka dapat berlatih terlebih dahulu. Ketiga, prosedur penilaian harus disampaikan secara jelas dan sistematis agar proses penilaian berjalan dengan baik. Keempat, tanamkan kepada siswa bahwa kejujuran dan objektivitas sangat dijunjung tinggi dalam proses penilaian ini, sehingga mereka sadar bahwa memiliki tanggung jawab dalam proses penialaian. Kelima, penilaian peer assessment dapat dijadikan sebagai salah satu penilaian sumatif ketika dilakukan secara akuntabel.

\section{DAFTAR PUSTAKA}

[1]. Thaiposri P WP. Enhancing students' critical thinking skills through teaching and learning by inquiry-based learning activities using social network and cloud computing [Internet]. Procedia Soc Behav. 2015. p. 37-44. 
Available

from:

http://dx.doi.org/10.1016/j.sbspro. 2015.02.013

[2]. Trevithick P. Social Work Skills And Knowledge: a practice handbook. Mc Graw Hill Open University: New York; 2012. 291 p.

[3]. Griffin P CE. Assessment and Teaching of 21st Century Skills: Methods and Approach. Assessment and teaching of 21st century skills. Dordr Heidelb New York London Springer. 2005;293310.

[4]. Živković S. The Importance Of Oral Presentations For University Students. Mediterr J Soc Sci. 2014;5(19):468-75.

[5]. Mandel S. Effective Presentation Skills: A Practical Guide for Better Speaking. Boston: Course Technology; 2000.

[6]. Segara NB, Yana E, Febianti YN. THE BENEFITS OF PEER ASSESSMENT TO ASSESS ORAL PRESENTATION OF ECONOMICS EDUCATION STUDENTS UNSWAGATI CIREBON. In: The 1st International Conference on Economics, Education, Business, and Accounting (ICEEBA 2016). 2014. p. 110-23.

[7]. Topping KJ. Peer assessment. Theory Pract. 2009;48(1):20-7.

[8]. Chen YC, Tsai CC. An educational research course facilitated by online peer assessment. Innov Educ Teach Int. 2009;46(1):10517.

[9]. Grez D, Valcke, Berings. Peer assessment of oral presentation skills. Procedia - Soc Behav Sci. 2010;2(2):1776-80.

[10]. Grez L De, Valcke M, Roozen I.
Higher Education Research \& Development The differential impact of observational learning and practice- based learning on the development of oral presentation skills in higher education. High Educ Res Dev. 2013;33(2):256-71.

[11]. Segara NB, Yana E, Febianti YN. Developing an Oral Presentation Assessment to the Teacher Education Program Student. Int Educ Res. 2018;1(1):43-50.

[12]. De Grez, Valcke B. Student response system and learning oral presentation skills. [Internet]. Procedia - Soc Behav. 2010. p. 69. Available from: http://dx.doi.org/10.1016/j.sbspro. 2010.03.985

[13]. van Ginkel S, Gulikers J, Biemans $\mathrm{H}$, Mulder $\mathrm{M}$. The impact of the feedback source on developing oral presentation competence. Stud High Educ. 2017;42(9):167185.

[14]. Turner K, Roberts L, Heal C, Wright L. Oral presentation as a form of summative assessment in a master's level PGCE module: The student perspective. Assess Eval High Educ. 2013;38(6):662-73.

[15]. Kim HS. Uncertainty analysis for peer assessment: Oral presentation skills for final year project. Eur J Eng Educ. 2014;39(1):68-83.

[16]. White E. Student Perspectives of Peer Assessment for Learning in a Public Speaking Course. Asian EFL J - Prof Teach Artic. 2009;33:1-55.

[17]. Bhati SS. The Effectiveness of Oral Presentation Assessment in a Finance Subject: An Empirical 
Examination. J Univ Teach Learn Pract. 2012;9(2):1-23.

[18]. Yang YF, Tsai CC. Conceptions of and approaches to learning through online peer assessment. Learn Instr. 2010;20(1):72-83.

[19]. Suñol JJ, Arbat G, Pujol J, Feliu L, Fraguell RM, Planas-Lladó A. Peer and self-assessment applied to oral presentations from a multidisciplinary perspective. Assess Eval High Educ. 2016;41(4):622-37.

[20]. Ridwan AE. Pendidikan IPS dalam membentuk SDM beradab. Jurnal Pendidikan IImu Sosial. 2014;23(1).

[21]. Magin D, Helmore P. Peer and Teacher Assessments of Oral Presentation Skills: How reliable are they? Stud High Educ. 2001;26(3):286-98.

[22]. Aryadoust V. Self- and Peer Assessments of Oral Presentations by First-Year University Students. Educ Assess.
2015;20(3):199-225.

[23]. Berry R. Assessment for Learning. Hong Kong University Press; 2008.

[24]. Ravand H, Baghaei P. Partial Least Squares Structural Equation Modeling with R CB-SEM vs PLSSEM. Pract Assessment, Res Eval. 2016;21(11):1-16.

[25]. Ghozali I, Latan H. Partial Least Squares: Konsep, Teknik dan Aplikasi Menggunakan Program SMART PLS 3.0 Untuk Penelitian Empiris. Semarang: Badan Penerbit Universitas Diponegoro; 2015.

[26]. Sudiyanto S, Kartowagiran B, Muhyadi M. Pengembangan Model Assessment As Learning Pembelajaran Akuntansi Di Smk. J Penelit dan Eval Pendidik. 2015;19(2):189-201. 